\title{
食酢もろみから分離した酢酸菌の同定 ${ }^{\dagger}$
}

\author{
南 場毅* • 加藤熙*

\begin{abstract}
Identification of Acetic Acid Bacteria Isolated from Vinegar Mash
(Studies on the Substances to Stimulate Acetic acid Fermentation Part VIII)
\end{abstract} \\ Tsuyoshi NanBa* and Hiroshi KaTo* \\ * Food Research Institute, Aichi Prefectural Government, Nishi-ku, Nagoya, 451
}

\begin{abstract}
Acetobacter strain No. 2 and Acetobacter strain M-1 were non-motile, gram-negative rods and had the Q-9 (Q-8) system. They oxidized both acetate and lactate, and produced acetic acid from ethanol, however, did not produced dihydroxyacetone from glycerol and water soluble brown pigments. Growth on Hoyer-Frateur medium, the formation of thick pellicle or the formation of ferric chloride-positive substance in glucose and fructose broth were not observed. Acetobacter strain M-1 had the ability to grow on glutamate agar, and to produce acids from L-arabinose and D-galactose, whereas Acetobacter strain No. 2 did not have such properties. From these results, Acetobacter strain No. 2 and Acetobacter strain M-1 were identified as Acetobacter pasteurianus.
\end{abstract}

(Received Aug. 11, 1984)

前報までに, 種々の天然栄養源中の有效成分の分離,

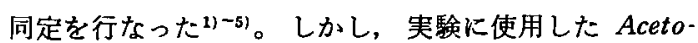
bacter No. 2 菌(6)，Acetobacter M-1 菌とも未同定であ った。

体報では，画菌の菌学的検討を行ない，同定したので 報告する。

\section{実 験 方 法}

\section{1. 供試菌株}

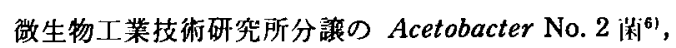
愛知県下の $\mathrm{M}$ 工場の種酢から分離した Acetobacter M1 菌を使用した。対照として Acetobacter aceti subsp. liquefaciens IAM 1834 および Gluconobacter oxydans NCIB 9013, Acetobacter aceti IFO 3281, Acetobacter aceti ATCC 15973 を使用した。

2. 形状, 大きさ

PGY 培地（グルロース，醉母エス，ポリペプトン 各 $1 \%$, ×チルアルコール $5 \%$, 寒天 $2 \%$ 含有) で $30^{\circ} \mathrm{C}$, 24 時間培養し, サフラニンで染色後, 顕微鏡観察および
字真撮影を行なった。

3. グラム染色

PGY 培地で $30^{\circ} \mathrm{C}, 24$ 時間培着後, HUCKER 変法" $\mathrm{K}$ より行なった。

\section{4. 運動性}

PGY 培地, 保存用培地 扰よび数エキス寒天培地を用 い, $15^{\circ} \mathrm{C}, 20^{\circ} \mathrm{C}, 25^{\circ} \mathrm{C}$ おび $30^{\circ} \mathrm{C} て ゙ 18 \sim 24$ 時間それ ぞれ生育させ，惩滴法8 で観察した。

\section{5. 培地 $\mathrm{pH}$ の生育への影響}

グルコース $2 \%$ ，エタノール $0.5 \%$ ，醉母ェス 0.5 $\%$ ，ポリペプトン $0.3 \%$ の組成の培地をそれぞれ $\mathrm{pH}$ $3.0,3.5,4.0,4.5,5.0,6.0,7.0$ 亿調製し， $30^{\circ} \mathrm{C}$ で 7 日間培差し, 分光光度計 $(660 \mathrm{~nm})$ で判定して生育の 有無を判定した。

\section{6. 色素生成"}

培地中打よび菌体に甜ける色素生成はタルコース 3 $\%$, 醉母ェキス $0.2 \%$, ポリペプトン $0.3 \%$, 炭酸カル シゥム $2 \%$, 寒天 $2 \%$ の斜面培地代菌を接種し， $30^{\circ} \mathrm{C}$ にて 10 日間培養し，色素生成の有無を観察した。 


\section{7. 酢酸および乳酸の酸化能 ${ }^{10)}$}

炭素源として酰酸ナトリウムもしくは乳酸ナトリウム $0.2 \%$ を含み，他に酵母エキス $0.2 \%$ ，ボリペプトン $0.3 \%, \mathrm{pH}$ 指示薬として B.T. B. (ブロムチモールブル 一) $0.002 \%$ を加えた培地（pH 6.4）を調製し， $30^{\circ} \mathrm{C}$ ， 7 日間培着後, 培地の色調変化により酸化能の有無を調 べた。

\section{8. 乳酸晧の炭酸塩への分解11}

乳酸カルシウム $1 \%$, 酵母エキス $1 \%$, 寒天 $2 \%$ の培 地で $30^{\circ} \mathrm{C} ， 10$ 日間培養し，コロニ一周辺に拈ける炭酸 カルシウムの結晶の生成の有無により分解度を判定し た。

\section{9. グルタミン酸ナトリウム寒天培地での生育 ${ }^{12}$}

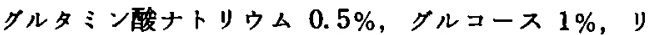
酸-1ーカリウム $0.1 \%$, 硫酸マグネシウム・7水塩 0.02

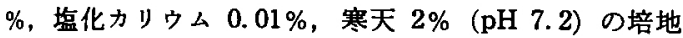
で，30 $\mathrm{C} ， 10$ 日間培養し，生育状態により判定した。

\section{0. マンニトール寒天培地での生育 ${ }^{9}$}

マンニトール $2.5 \%$, 酵母エキス $0.5 \%$ ，ポリペプト ン $0.3 \%$, 寒天 $2 \%\left(\mathrm{pH} \mathrm{6.0)}\right.$ の培地で, $30^{\circ} \mathrm{C}, 10$ 日 間培養し，生育状熊により判定した。

\section{HOYER-FRATEUR 培地での生育 ${ }^{13)}$}

エチルフルコール $3 \%(v / v)$, 硫安 $0.1 \%$ ，リン酸一 2-カリウム $0.01 \%$ ，リン酸-1ーカリウム $0.09 \%$, 硫酸 マグネシウム・7 水塩 $0.025 \%$ ，塩化第 2 鉄 $0.0005 \%$ の $5 \mathrm{~m} l$ あるいは $10 \mathrm{ml}$ の容量の培地で $30^{\circ} \mathrm{C}, 20$ 日間, 静置または振と弓培養し， $\mathrm{N} / 10 \mathrm{NaOH}$ 滴定值 $5 \mathrm{ml}$ 以 上の場合にアンモニウム塩の資化性ありと判定した。

\section{2. グリセリンからの ketogenic activity}

ダリセリン $3 \%$ ，醳母エキス $0.5 \%$ ，ポリペプトン 1 \%（pH 6.0）の培地で $30^{\circ} \mathrm{C} ， 14$ 日間培盖した。フェー リング溶液を培地に添加し，赤レンガ色に呈色したもの を ketogenic activityを有するものと判定した。

13. グルコースおよびフルクトースからの塩化第 2 鉄 反応物の生成能”

グルコースまたはフルクトース $5 \%$ ，酵母ェキス 0.5 $\%$ ，ポリペプトン $0.5 \%$ および炭酸カルシウム $0.5 \%$ の培地を使用し，コージ酸など塩化第 2 鉄反応物の生成 能を試釦した。 $30^{\circ} \mathrm{C} て ゙ 15$ 日間培養後，5\% 塩化第 2 鉄 客液添加によって赤褐色を呈する菌株は塩化第 2 鉄反応 物の生成能を有するむのとした。

\section{4. 䓂およひ裾アルコールからの酸生成能 ${ }^{9}$}

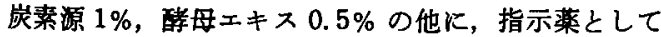
B.C.P. (ブロムクレソールパープル) $0.02 \%$ を含む $\mathrm{pH}$
6.8 の培地を調製し，30， 7 日間，培盖し，酸生成の 有無は，B.C.P. の呈色すなわち，酸性 $\mathrm{pH} て ゙$ 黄色とな ることで判別した。炭素源には $\mathrm{D}^{-}$キシロース， L アラ ビノース，D-グルコース，D-マンノース，D-ガラクトー 、, D-フルクトース, D-ソルボース, スクロース, マル

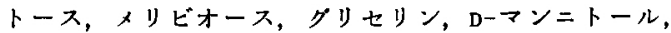
D-ソルビトール， エチルフルコールの 14 種の糖および 糖フルコールを使用した。

\section{Ubiquinone system $\sigma$ 決定}

YAMADA et al.14) の方法によった。ペーパークロマト グラフィーの容媒はェチルアルコール：酢酸エチル：水 $=5: 3: 1$ および $\mathrm{N}, \mathrm{N}^{\prime}$-ジメチルフォルムアミド：水= $97: 3$ を用いた。

\section{実験結果及び考察}

1. 供試菌株の同定

(1) 形熊学的性質

Photograph 1〜3 および Table 1 に示すように, い ずれの菌株む桿菌で，運動性はみられず，グラム染色は

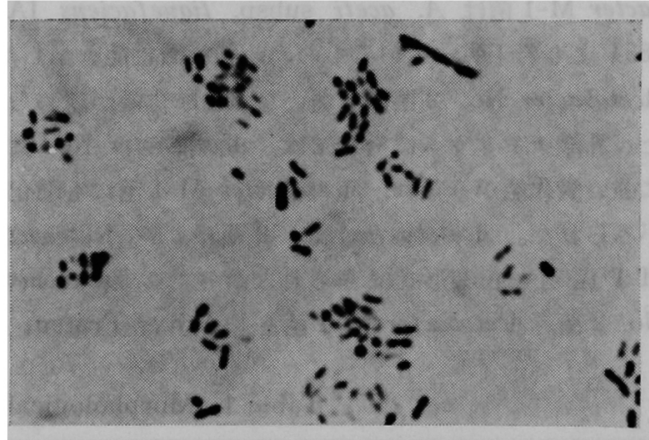

Photograph 1 Acetobacter strain No. 2 After incubated on PGY agar medium at $30^{\circ} \mathrm{C}$ for $24 \mathrm{hr}$

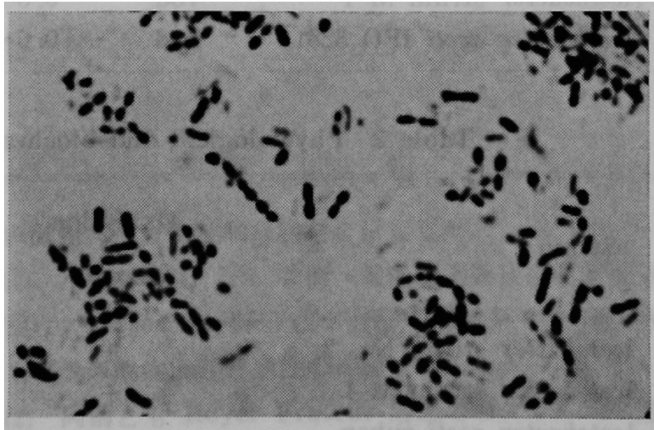

Photograph 2 Acetobacter strain M-1 After incubated on PGY agar medium at $30^{\circ} \mathrm{C}$ for $24 \mathrm{hr}$ 


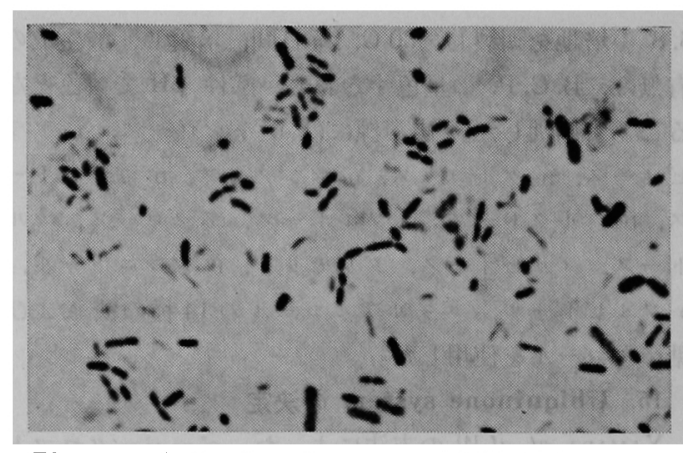

Photograph 3 Acetobacter aceti IFO 3281

After incubated on PGY agar medium at $30^{\circ} \mathrm{C}$ for $24 \mathrm{hr}$

陰性で，大きさは Acetobacter の数値 ${ }^{15)}$ とほぼ一致し ていた。

\section{（2）生理学的性質}

酢酸ナトリウム, 乳酸ナトリウムの酸化能, HoyerFrateur 培地での資化性および色素生成の結果を Table 2 に示した。酢酸ナトリゥムの酸化能において, Acetobacter M-1 菌は $A$. aceti subsp. liquefaciens IAM 1834 より若干劣っているものの, 强い酸化能を示した。 Acetobacter No. 2 菌にも弱いながら酸化能が認められ た。乳酸ナトリウムに対しては, Acetobacter No. 2 菌 に強い酸化能がみられ, Acetobacter M-1 菌にも酸化能 がみられた。Acetobacter No. 2 菌および Acetobacter M-1 菌とも色素形成はみられなかった。Acetobacter No. 2 菌, Acetobacter M-1 菌とも Hoyer-Frateur 培
地で生酸はみられず，表に示さなかったが，対照に用い た Acetobacter aceti IFO 3281 および Acetobacter aceti ATCC 15973 とも生酸はみられ, Acetobacter aceti subsp. liquefaciens IAM 1834 は生育がみられ, Acetobacter No. 2 菌, Acetobacter M-1 菌ともフンモ こア態窒素の資化性はないと考えられた。

グルタミン酸ナトリウム寒天培地, マンニトール寒天 培地での生育, グリセリンからのジヒドロキシアセトン 生成, グルニース, フルクトース培地での塩化第 2 鉄反 応物の生成能, Thick pericle の形成の有無を Table 3 に示した。グルタミン酸ナトリウム寒天培地では Acetobacter M-1 菌に生育が認められ, Acetobacter No. 2 菌 の揚合は菌膜が点在する程度の弱い生育であった。マン ニトール寒天培地では Acetobacter No. 2 菌, Aceto. bacter $\mathrm{M}-1$ 菌とも生育は認められなかった。グリセリ ンからの DHA（ジヒドロキシアセトン）生成は認めら れず，塩化第 2 鉄反応物の生成もグルュース，フルクト 一ス両培地で Acetobacter No. 2 菌, Acetobacter M1 菌とも認められなかった。Thick pericle の形成も認 められず, Acetobacter xylinum の可能性は否定された。

楛, 糖アルコールからの酸生成は Table 4 に示すよ らに, Acetobacter No. 2 菌では D-キシャース, D-グル コース，D-マンノースから Acetobacter M-1 菌ではそ の他に Lーフラビノース，D-ガラクトースから酸生成が みられたが，両菌とす糖からの酸生成能は弱かった。 Ubiquinone system 抽び pH と生育の関係の結果を Table 5 に示す。全ての pH 領域で Acetobacter No.2

Table 1 Morphological characteristics of used strains

\begin{tabular}{lccccc}
\hline Strain & Form & Size $(\mu \mathrm{m})$ & Motility & Flagellum & Gram stain \\
\hline Acetobacter strain No. 2 & short rod & $0.7 \sim 0.9 \times 1.0 \sim 1.4$ & - & none & negative \\
Acetobacter strain M-1 & rod & $0.6 \sim 0.8 \times 1.0 \sim 1.2$ & - & none & negative \\
Acetobacter aceti IFO 3281 & rod & $0.6 \sim 0.7 \times 1.2 \sim 1.6$ & - & none & negative \\
\hline
\end{tabular}

Table 2 Physiological and biochemical characteristics of used strains (I)

\begin{tabular}{|c|c|c|c|c|c|}
\hline Strain & $\begin{array}{l}\text { Oxidation } \\
\text { of } \\
\text { acetate }\end{array}$ & $\begin{array}{c}\text { Oxidation } \\
\text { of } \\
\text { lactate }\end{array}$ & $\begin{array}{l}\text { Oxidation } \\
\text { of } \\
\text { lactate to } \\
\text { carbonate }\end{array}$ & $\begin{array}{l}\text { Growth } \\
\text { on } \\
\text { Hoyer-Frateur } \\
\text { medium }\end{array}$ & $\begin{array}{l}\text { Pigmen- } \\
\text { tation }\end{array}$ \\
\hline Acetobacter strain No. 2 & + & + & + & - & - \\
\hline Acetobacter strain $\mathrm{M}-1$ & + & + & + & - & - \\
\hline $\begin{array}{l}\text { Acetobacter aceti subsp. } \\
\quad \text { liquefaciens IAM } 1834\end{array}$ & + & + & + & $+^{59)}$ & + \\
\hline Gluconobacter oxydans NCIB 9013 & - & - & - & - & - \\
\hline
\end{tabular}


Table 3 Physiological and biochemical characteristics of used strains (II)

\begin{tabular}{|c|c|c|c|c|c|c|}
\hline Strain & $\begin{array}{l}\text { Growth } \\
\text { on } \\
\text { glutamate } \\
\text { agar }\end{array}$ & $\begin{array}{l}\text { Growth } \\
\text { on } \\
\text { mannitol } \\
\text { agar }\end{array}$ & $\begin{array}{c}\text { Thick } \\
\text { pellicle } \\
\text { formation }\end{array}$ & $\begin{array}{c}\mathrm{FeCl}_{\mathrm{s}} \\
\underset{\text { glucose }}{\text { broth }}\end{array}$ & $\begin{array}{c}\text { tion in } \\
\text { fructose } \\
\text { broth }\end{array}$ & $\begin{array}{c}\text { DHA* } \\
\text { from } \\
\text { glycerol }\end{array}$ \\
\hline Acetobacter strain No. 2 & - & - & - & - & - & - \\
\hline Acetobacter strain $\mathrm{M}-1$ & + & - & - & - & - & - \\
\hline $\begin{array}{l}\text { Acetobacter aceti subsp. } \\
\text { liquefaciens IAM } 1834\end{array}$ & + & + & - & + & + & + \\
\hline $\begin{array}{l}\text { Gluconobacter oxydans } \\
\text { NCIB } 9013\end{array}$ & - & + & - & - & + & + \\
\hline
\end{tabular}

Table 4 Physiological and biochemical characteristics of used strains (III)

\begin{tabular}{|c|c|c|c|c|c|c|c|c|c|c|c|c|c|c|}
\hline \multirow[b]{2}{*}{ Strain } & \multicolumn{14}{|c|}{ Acid formation from } \\
\hline & 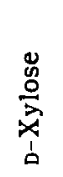 & 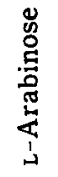 & 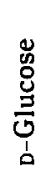 & 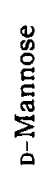 & 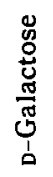 & 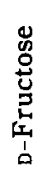 & 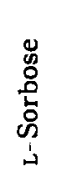 & 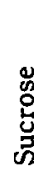 & 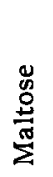 & 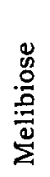 & $\begin{array}{c}\overline{0} \\
\frac{0}{0} \\
\frac{0}{0}\end{array}$ & 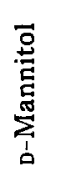 & 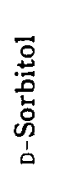 & 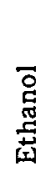 \\
\hline Acetobacter strain No. 2 & + & - & + & + & - & - & - & - & - & - & - & - & - & + \\
\hline Acetobacter strain M-1 & + & + & + & + & + & - & - & - & - & - & - & - & - & + \\
\hline $\begin{array}{l}\text { Acetobacter aceti subsp. } \\
\text { liquefaciens IAM } 1834\end{array}$ & + & + & \pm & + & \pm & \pm & + & + & - & + & - & - & - & + \\
\hline Gluconobacter oxydans NCIB 9013 & + & + & + & + & + & + & + & + & + & + & + & + & + & + \\
\hline
\end{tabular}

Table 5 Physiological and biochemical characteristics of used strains (IV)

\begin{tabular}{|c|c|c|c|c|c|c|c|c|}
\hline \multirow{2}{*}{ Strain } & \multirow{2}{*}{$\begin{array}{l}\text { Ubiquinone } \\
\text { system }\end{array}$} & \multicolumn{7}{|c|}{ Growth at $\mathrm{pH}$} \\
\hline & & 3.0 & 3.5 & 4.0 & 4.5 & 5.0 & 6.0 & 7.0 \\
\hline Acetobacter strain No. 2 & $Q-9(Q-8)$ & + & + & + & + & + & + & + \\
\hline Acetobacter strain $\mathbf{M}-\mathbf{l}$ & $Q-9(Q-8)$ & + & + & + & + & + & + & + \\
\hline $\begin{array}{l}\text { Acetobacter aceti subsp. } \\
\text { liquefaciens IAM } 1834\end{array}$ & $Q-10(Q-9)$ & + & + & + & + & + & + & + \\
\hline $\begin{array}{l}\text { Gluconobacter oxydans } \\
\text { NCIB } 9013\end{array}$ & Q-10 & - & + & + & + & + & + & + \\
\hline
\end{tabular}

菌, Acetobacter M-1 菌とも生育が認められた。Ubiquinone system は両菌の菌体抽出物のペーパークロマト クラフィーの結果, Ubiquinone-9 の他に Ubiquinone8 のスポットが認められ，YAMADA et al.14) の Acetobacterでの結果とよく一致していた。以上の結果から, Bergey's mannual 8th Ed. ${ }^{16)}$ により, Acetobacter No. 2 菌扰よび Acetobacter $\mathrm{M}-1$ 菌を Acetobacter pasteurianus と同定した。

\section{要 約}

供試菌株の分類学的な検討を行なった。

(1) Acetobacter No. 2 菌（钽生物工業技術研究所分 変菌), Acetobacter M-1 菌（食酢もろみからの分離菌） ともグラム陰性, 非運動性の程菌であった。

(2) 菏菌ともHoyer Frateur 培地でのアンモニア態 窒素の資化性はなく，クリセリンからのジヒドロキシフ 七トンの生成, 色素, Thick pericle の生成は認められ 
なかった。また，Acetobacter No. 2 菌は D-キシロー ス, D-グルュース, D-マンノースから, Acetobacter M -1菌ではその他に L-フラビノース，D-ガラクトースか ら酸生成が認められた。以上の結果から，Bergey's mannual 8th Ed. により雨荣はともに Acetobacter pasteurianus と同定した。

終りに臨み，菌株の同定に御指導，御鞭達を賜わりま した静岡大学農学部 山田婎三教授, 東京農業大学 好 井久雄教授に御礼申し上げます。

\section{文献}

1) 南場 毅 - 竹内德男: 日食工誌, 24, 570 (1977).

2) 南場 效 - 竹内徳男：日食工誌, 24, 576 (1977),

3）南場 媇-竹内德男: 日食工誌, 27, 136 (1980).

4) 南場 敖 - 㸝内德男：日食工誌, 28, 534 (1981).

5) 南場 毅 - 加藤 熙：日食工誌, 30, 191 (1983).

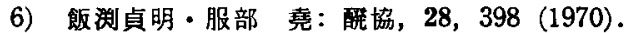

7) 伝染病研究所学友会：細菌学実習提要（丸善, 東
京), p. 119 (1958)

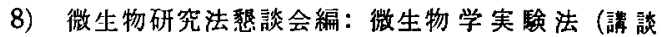
社), p. 134 (1975).

9) Asai, T., Iizuka, H. and Komagata, K.: J. Gen. Appl. Microbiol., 10, 95 (1964).

10) Leifson, E.: Antonie van Leuwenhook: $J$. Microbiol. Serol., 20, 102 (1954).

11) Shimwell, J. L., Carr, J. G. and Rhodes, M. E. J. Gen. Microbiol., 28, 283 (1960).

12) Ilzuka, H. and Komagata, K.: J. Gen. Micro. biol., 9, 73 (1963).

13) Frateur, J.: La Cellule, 53, 333 (1950).

14) Yamada, Y., Aida, K. and Uemura, T.: $J$. Gen. Appl. Microbiol., 15, 181 (1961).

15）柳田滕治 - 山本 泰・西島英雄・住江金之：醘協， 69, 517 (1974).

16) Deley, J. and Frateur, J.: In Bergey's Mannual of Determinative Bacteriology, 8th Ed., ed by R.E. Buchanan and M.E. Gibbons, The Williams \& Wilkins, Co., Baltimore, p. 251 (1974).

(昭和 59 年 8 月 11 日受理) 